\title{
Lila Falling
}

\section{J. Kevin Carmichael, $M D$}

I have a dream.

A dream of someone falling.

Gravity takes hold. The acceleration is not sensed. The speed is not apparent. The fall is long. The ground rushes up. I wake up tired, shower, shave, and drive through the still-dark streets to start another day.

Perhaps you read the story in the paper. I saw it on television. "Tucson Woman Dead in Airplane Over Omaha, Nebraska." I was making rounds in the hospital, the television was on in every room. I saw the newscast graphic and paused to listen to the story of the woman from Tucson found dead in an airplane lavatory. I didn't hear her name, but one of my patients did and called the office to tell us it was Lila.

The last time I saw Lila, she walked into the clinic without an appointment. She was just out of jail and had to see me. I sent a medical student to see her while I finished up with other patients. She had a bag of ice cubes. She was rubbing ice cubes all over her body. She couldn't sit. She was all wet. Her skin was hot. Her muscles went into spasms. She hadn't slept in several days but was trying to now, even while she stood, jerking, dripping, frightened, falling.

Submitted 12 July 1999.

From a private practice. Address reprint requests to J. Kevin Carmichael, MD, El Rio Special Immunology Associates, 1701 W St Mary's, Suite 100, Tucson, AZ 85745.
The medical student looked somewhat relieved when I came in. We took Lila to the emergency department. Her ice went, too. Intravenous lorazepam helped. Her urine test was positive for cocaine, amphetamines, and heroin. She had been using her external jugular vein. I admitted her to the hospital. The police arrested her the next day for violating parole. The guards shackled her to the bed. I transferred her care to the Department of Corrections. She was soon discharged back to jail.

Lila's mother called my nurse, Janie. Together they arranged a hotel room for the night after her release. Her mother sent an airplane ticket (nonrefundable). Janie took Lila to the airport and saw her on the plane. She was flying home to her family and another drug-treatment program.

The flight attendants tried CPR. I imagine Lila and the syringe in the airplane lavatory. I remember her wild clothes, her multiple tattoos, her body piercings, her track marks. I remember trying to help her with her addiction. I remember the panic always in her eyes.

I rock climb and have caught and held my partner's falls. I have read the reports of falls not held and climbers who have died. I have seen the scars on the hands of a friend who held a very long fall. The rope burned deep, but he saved his partner's life.

Where do the scars of the falls not held appear? I search my hands, my face, my heart.

I dream of Lila.

Falling. 